\title{
Debate, revisão por pares, Galileu Galilei mais uma vez...
}

Há menos de meio milênio, a história presenciou um período de grande efervescência intelectual, cultural e de grandes descobertas. Leonardo da Vinci, Cristóvão Colombo, Nicolau Copérnico, Michelangelo, Shakespeare, Isaac Newton, René Descartes e Galileu Galilei são alguns dos expoentes da era da Renascença. A visão do homem, como "centro do universo", desencadeou uma fase iluminada após as "trevas" da Idade Média, cujas imposições religiosas e o medo obstruíam as novas idéias. $\mathrm{O}$ conceito do método científico, iniciado por Galileu, contribuiu para desenhar os métodos que praticamos ainda hoje. O cientista pregava, já naquela época, a atualíssima fiscalização por pares como forma de controle das novas descobertas. Concebia ele, que o conhecimento poderia avançar com o crivo de um grupo de cientistas que julgariam as novas teorias. Em resumo, após a exposição de uma idéia, a revisão pelos pares é que a perpetuaria, aceitando-a ou refutando-a. Em outras palavras, os debates e as discussões é que geram a verdadeira ciência.

Seguindo o exemplo dos periódicos internacionais, pouco a pouco, podemos perceber este espírito do debate e das discussões em nossos leitores. Na edição passada, publicamos uma carta questionando alguns dos itens de um experimento sobre as estruturas metálicas dos braquetes, que havia ilustrado a edição julho/agosto de 2004. No presente número, publicamos as respostas dos autores, esclarecendo os fatos. Aliado ao nosso gratificante caráter técnico como publicação científica, nos sentimos extremamente lisonjeados em atuar como veículo da argumentação. Além de meio divulgador das pesquisas realizadas no Brasil e fora dele, nosso ideal como Revista é receber e publicar, com mais freqüência, questionamentos de importância no contexto científico ortodôntico. Apraz-nos constatar que esse papel já é exercido pelos nossos consultores com suas criteriosas revisões, que refinam e qualificam o verdadeiro fórum de discussões promovido pelo nosso público leitor.

Ainda nessa linha de "apresentação" da ciência, a revista Veja, no início de novembro, expôs o conceito da revisão por pares, direcionando-o para a importância das citações. Isto é, a importância de um trabalho científico, ou do autor dele é medida pelo número de vezes em que o mesmo é mencionado por outros pesquisadores. Com a comunicação global permitida pela internet, um trabalho que gerou um grande impacto no meio científico a que pertence, será citado como referência em vários outros. Ainda que seja com algum grau de limitação, obtemos o que chamamos de fator de impacto - que está vinculado à revista que o publicou. Portanto, se um trabalho (ou uma revista científica) teve um grande fator de impacto, é porque realmente repercutiu no meio a que pertence.

Também no início de novembro, tivemos a oportunidade de acompanhar um fórum de discussões no Encontro Internacional de Editores e Autores de Revistas Científicas na Área de Odontologia, realizado na Faculdade de Odontologia de Bauru-SP e do qual participaram, além de diversos editores nacionais, cinco editores de revistas internacionais de Odontologia de grande impacto. Na ocasião, pudemos concluir que o fator de impacto, da forma como é calculado hoje, apresenta limitações e necessita reavaliações. Apesar disso, ele continua a ser um parâmetro razoável de repercussão no meio científico, pois mede de alguma forma se o trabalho foi importante para novos estudos, para os debates, para as discussões, e como trampolim para novos avanços. Outra conclusão do evento sugere que revisões sistemáticas da literatura geram um alto fator de impacto e resgatam a importância de trabalhos clássicos, tornando-se necessárias também nos periódicos.

Embora não qualificada exatamente como uma revisão sistemática, nos sentimos privilegiados em acreditar na seção Tópico Especial, marca registrada da Revista Dental Press de Ortodontia e Ortopedia Facial desde o seu primeiro número, e que apresenta uma revisão liderada por um pesquisador de renome sobre o tema. Nosso aval se estende também aos artigos de revisão, independentemente do tópico especial, já que os mesmos geram debates e discussões, indo de encontro às questões dogmáticas. Tudo isso sem esquecer do caráter inovador e da curiosidade inerentes aos novos experimentos apresentados nos artigos inéditos.

Além dos artigos, a seção Entrevista, confirma nosso privilégio de poder contar com o crédito da comunidade ortodôntica nacional e internacional. Já são 38 entrevistas científicas nestes 8 anos de edição, das quais participaram 19 personalidades brasileiras e 19 do exterior (EUA, Canadá, Suécia, Suíça, Holanda, Dinamarca, Noruega, Japão, Argentina e México). Por essas e outras razões, na publicação deste bimestre temos o orgulho de contar com a exposição do ilustre Prof. Dr. Vincent Kokich, reconhecido mundialmente pelo critério rigoroso em publicações e pelo esmero clínico. Esperamos que o conteúdo de todos os artigos desta edição, incluindo o Tópico Especial e, sem margem de dúvidas esta entrevista, promovam a repercussão aos pares.

Galileu Galilei (1564-1642), tão antigo e tão atual. Mais uma vez seu conceito de revisão por pares desponta como mais uma das suas importantes idéias. Não é à toa que podemos considerá-lo como um pesquisador de "real" fator de impacto!

Adilson Luiz Ramos Editor 